\title{
Freshwater Amphipod Species of Western Anatolia, Marmara and Turkish Thrace Regions
}

\author{
Mehmet İpek1 (1), Murat Özbek² (1)
}

Cite this article as: Ipek, M., \& Ozbek, M. (2022). Freshwater amphipod species of western anatolia, marmara and turkish thrace regions. Aquatic Sciences and Engineering, 37(2), 74-85.

\author{
ORCID IDs of the author: \\ M.i. 0000-0002-7371-4587 \\ M.Ö. 0000-0003-4607-3507 \\ ${ }^{1}$ Eskişehir Osmangazi University, Faculty \\ of Science and Art, Eskişehir, Turkey \\ ${ }^{2}$ Ege University, Faculty of Fisheries, \\ İzmir, Turkey \\ Submitted \\ 24.09.2021 \\ Revision Requested: \\ 17.11.2021 \\ Last Revision Received: \\ 18.11.2021 \\ Accepted: \\ 17.12.2021 \\ Online Published: \\ 26.01.2022 \\ Correspondence: \\ Murat Özbek \\ E-mail: \\ ozbekm71@gmail.com
}

\begin{abstract}
To determine the Amphipoda (Crustacea) fauna of the inland waters of Western Anatolia, Marmara and the Turkish Thrace Region, field studies were conducted between May 2014 and March 2019. Seven field studies were conducted. Samplings were conducted at 291 localities and amphipod specimens were found at 127 of them. As a result, 11 amphipod species (Echinogammarus stocki G. Karaman, 1970, Gammarus aequicauda (G. Karaman, 1970), Gammarus anatoliensis Schellenberg, 1937, Gammarus arduus G. Karaman, 1975, Gammarus balcanicus Schäferna, 1923, Gammarus dorsosetosus Mateus \& Mateus, 1990, Gammarus gonensis Özbek, 2016, Gammarus komareki Schäferna, 1923, Gammarus lacustris G.O. Sars, 1863, Gammarus pulex pulex (Linnaeus, 1758), Gammarus uludagi G.S. Karaman, 1975) were determined. The new records can be listed as: E. stocki for Ekinanbarı, G. anatoliensis for Uşak, G. arduus for Bolu and Düzce, G. balcanicus for Kocaeli and Sakarya, G. dorsosetosus for Bolu, G. gonensis for Istanbul and Manisa, G. komareki for Düzce and Kocaeli, G. lacustris for Istanbul, G. pulex pulex for Bolu, Kırklareli, Kocaeli, Sakarya and Uşak, and G. uludagi for Aydın, Bilecik, Sakarya and Yalova provinces. The observed morphological features and the detailed drawings of the determined taxa are presented. Additionally, a map showing the distribution of the obtained species is also given.
\end{abstract}

Keywords: Inland-water, river, Peracarida, benthos, Malacostraca

\section{INTRODUCTION}

The order Amphipoda constitutes 30\% of the Malacostraca class, with more than 30,000 species worldwide. The number of marine, freshwater, brackish and terrestrial species (except Amphipoda with 22 species) is 10,247 worldwide (Horton et al., 2021). The taxonomy of the order Amphipoda has been finalized consisting of six suborders by the study of Lowry and Myers (2017). All of the amphipod species reported from the inland waters of Turkey belong to the suborder Senticaudata.

The pioneering study on the freshwater amphipod species of Turkey was reported by Vávra (1905) who described Gammarus argeaus from the Erciyes Mountains. After this initial study, many studies have been reported. The last study regarding the inland water amphipods of Turkey was on the identification of Rhipidogammarus gordankaramani Özbek \& Sket 2019 which was reported in Antalya.

In the present study, it is aimed to determine the Amphipoda fauna of the inland waters of Western Anatolia, Marmara and the Turkish Thrace Region.

\section{MATERIAL AND METHODS}

Seven field studies were conducted between May 2014 and March 2019 at 291 localities and amphipod specimens were found at 127 of them (Figure 1).

Samples were fixed in $96 \%$ ethyl alcohol in the field and then sorted in the laboratory using a 
Leica EZ4 stereomicroscope and then kept in 96\% ethyl alcohol. During the field study, altitudes, and geographical coordinates of the sampling localities were also noted (Table 1). Temporary slides of mature male specimens were prepared using pure glycerol. The photographs of the extremities were taken with a digital camera (Kameram21) attached to a microscope (Nikon Eclipse $80 \mathrm{i}$ ) and processed with image processing programs. A digitizer board (Wacom CTE-440) connected to a PC and its standard pen were used to draw illustrations on a transparent layer of the original photo of each extremity. Coleman (2003, 2006, 2009) was followed while drawing illustrations. Scale bars were marked using a micrometric slide for each magnification ratio of the microscope.

Karaman and Pinkster (1977a, 1977b, 1987), Bellan-Santini et al. (1982), Özbek (2011) and Pinkster (1993) were followed for the taxonomic identification.

The collected samples are stored in the laboratory of the Faculty of Science and Letters of Eskisehir Osmangazi University, Eskisehir, Turkey.

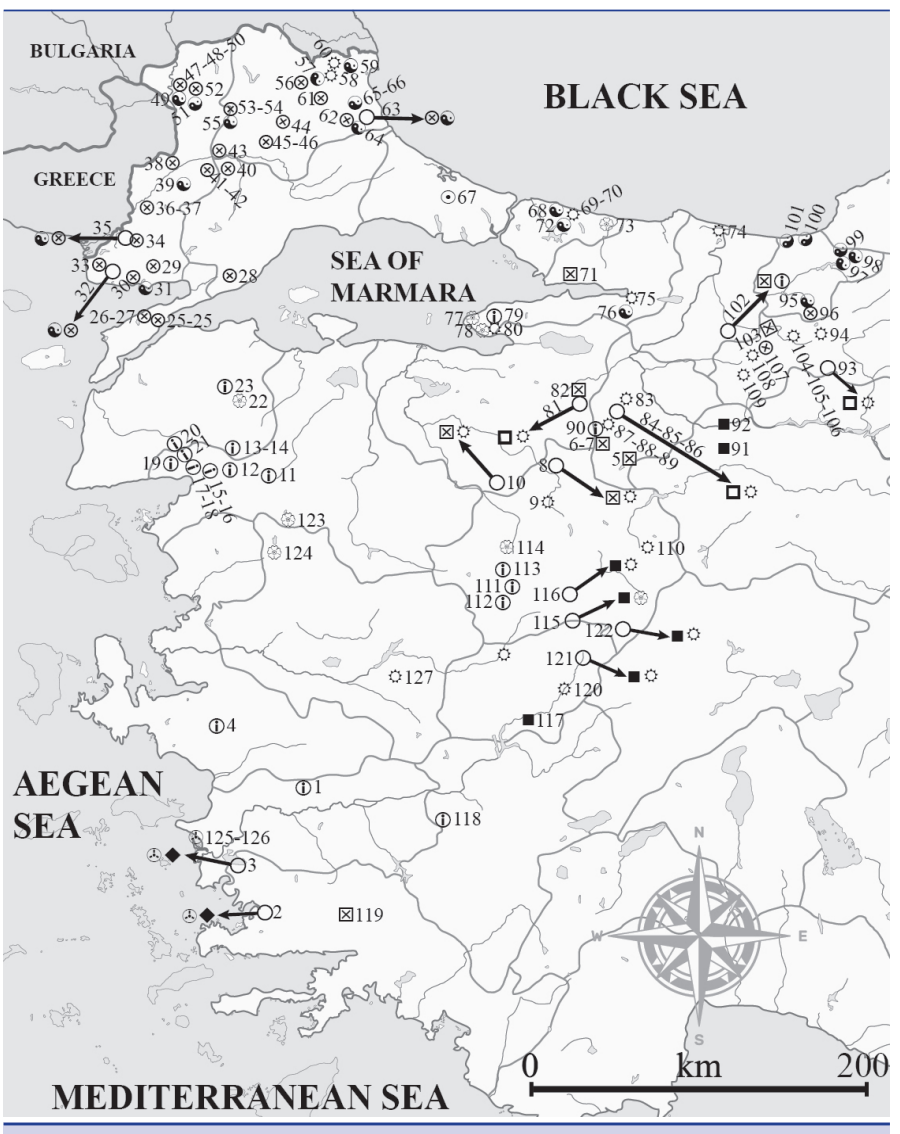

Figure 1. Distribution of the determined amphipod species species Echinogammarus stocki, Gammarus aequicauda, Gammarus anatoliensis, ®Gammarus arduus, 凶Gammarus balcanicus, 口Gammarus dorsosetosus, \& Gammarus gonensis, ๑Gammarus komareki, •Gammarus lacustris, Gammarus pulex pulex, (i) Gammarus uludagi).

\section{RESULTS AND DISCUSSION}

A total of 11 gammaridean taxa [Echinogammarus stocki G. Karaman, 1970, Gammarus aequicauda (G. Karaman, 1970), Gammarus anatoliensis Schellenberg, 1937, Gammarus arduus G. Karaman, 1975, Gammarus balcanicus Schäferna, 1923, Gammarus dorsosetosus Mateus \& Mateus, 1990, Gammarus gonensis Özbek, 2016, Gammarus komareki Schäferna, 1923, Gammarus lacustris G.O. Sars, 1863, Gammarus pulex pulex (Linnaeus, 1758), Gammarus uludagi G.S. Karaman, 1975] were recorded.

G. arduus was the most common species and sampled at 33 localities. G. komareki, G. pulex pulex, and G. uludagi were observed at 22, 21, and 18 localities, respectively. The distribution of the determined taxa and the information of the stations are presented (Figure 1, Table 2). The observed morphological features of the determined taxa are as follows:

E. stocki: A small species. The maximum body length is about $11 \mathrm{~mm}$ in adults. The antenna I reach half of the body and peduncle segments bear long setae along the posterior margins; the main and accessory flagellum consists of 20 and 4-5 segments, respectively. The fourth and fifth peduncle segments of antenna II bear 7-8 groups of long setae along the posterior margin, and the length of these setae are more than twice as long as the diameter of the segments on which they are implanted. Calceoli is absent. The mandibular palp has the characteristic C-setae. Endopodite of uropod III elongated and prominently as long as 1/5 of the exopodite and its length is three times as long as the wide. Exopodite with many plumose setae on both margins. Telson lobes are deeply cleft and about twice as long as their width.

Examined material: St. 2: 2 \%, 2 ổ, 17.v.2014; St. 3: 30 \%, 30 ổ, 17.v.2014.

G. aequicauda: The maximum body length is about 14-15 $\mathrm{mm}$ in adults. The main and accessory flagellum of antenna I consist of 28 and 6 segments, respectively. The fourth and fifth peduncle segments of antenna II bear many groups of long curled and simple setae on the posterior margins. Calceoli is absent. The third segment of the mandibular palp bears 2 groups of A-setae, 1 group of B-setae, 26 D-setae, and 4 E-setae. Gnathopod I is smaller than gnathopod II; propodus of the gnathopods I-II elongated and pyriform with a flask-shaped medial palmar spine. Pereiopods V-VII with long setae on the anterior margin. The basis of the pereiopod V-VI with 3-4 and 7-8 short setae on the postero-interior surface. Rami of the uropod III bears many plumose and simple setae. Telson lobes are very deeply cleft and about three times as long as their width. Each lobe with 2 groups of spines and setae on the outer margin, and 3 spines and 6-7 long setae on the terminal; setae longer than spines.

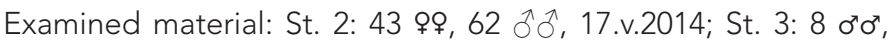

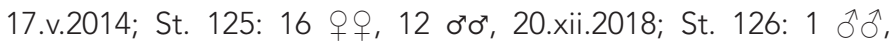
20.xii.2018.

G. anatoliensis: The maximum body length is about $14-15 \mathrm{~mm}$ in adults. Within the Gammarus balcanicus-group, it can be easily distinguished from the others by the elevated and crenulated dorsoposterior margins of the metasomal segments. Addition- 
Table 1. Taxonomic status, abbreviations (Abbr.) and newly recorded provinces of the determined taxa.

\begin{tabular}{|c|c|c|}
\hline Taxonomic status & Abbr. & Newly recorded locality \\
\hline $\begin{array}{l}\text { Genus: Echinogammarus Stebbing, } 1899 \\
\text { E. stocki G. Karaman, } 1970 \\
\text { Genus: Gammarus Fabricius, } 1775 \\
\text { G. aequicauda (Martynov, 1931) } \\
\text { G. anatoliensis Schellenberg, } 1937 \\
\text { G. arduus G. Karaman, } 1975 \\
\text { G. balcanicus Schäferna, } 1923 \\
\text { G. dorsosetosus Mateus \& Mateus, } 1990 \\
\text { G. gonensis Özbek, } 2016 \\
\text { G. komareki Schäferna, } 1923 \\
\text { G. lacustris G.O. Sars, } 1863 \\
\text { G. pulex pulex (Linnaeus, } 1758 \text { ) } \\
\text { G. uludagi G.S. Karaman, 1975 }\end{array}$ & $\begin{array}{l}\text { E.s. } \\
\text { G.ae. } \\
\text { G.an. } \\
\text { G.ar. } \\
\text { G.b. } \\
\text { G.d. } \\
\text { G.g. } \\
\text { G.k. } \\
\text { G.I. } \\
\text { G.p.p. } \\
\text { G.u. }\end{array}$ & $\begin{array}{l}\text { Uşak } \\
\text { Bolu and Düzce } \\
\text { Kocaeli and Sakarya } \\
\text { Bolu } \\
\text { Istanbul and Manisa } \\
\text { Düzce and Kocaeli } \\
\text { Istanbul } \\
\text { Bolu, Kırklareli, Kocaeli, Sakarya and Uşak } \\
\text { Aydın, Bilecik, Sakarya and Yalova }\end{array}$ \\
\hline
\end{tabular}

Table 2. The names, localities, sampling dates, geographical locations, and altitudes of the stations.

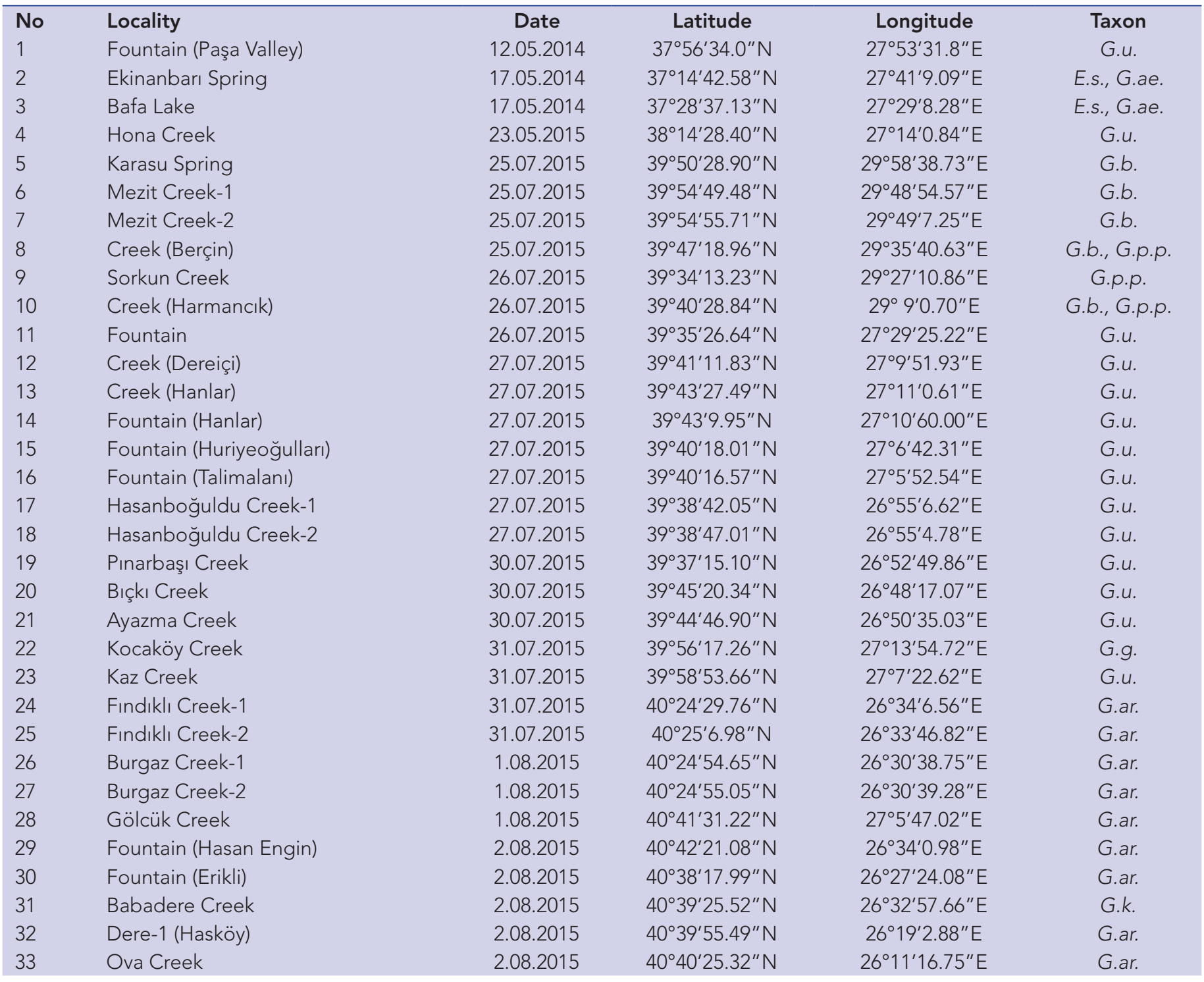




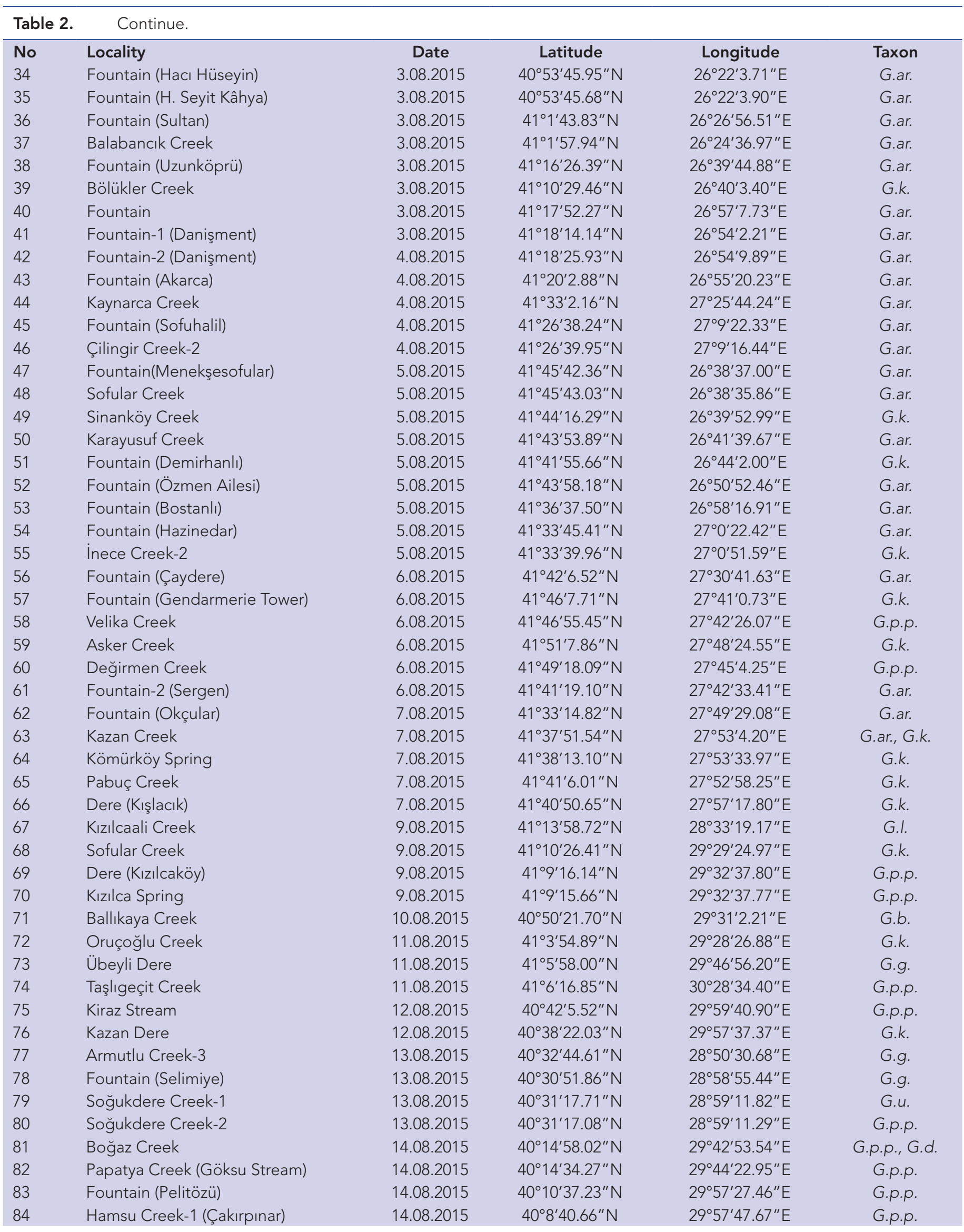




\begin{tabular}{|c|c|c|c|c|c|}
\hline No & Locality & Date & Latitude & Longitude & Taxon \\
\hline 85 & Hamsu Creek-2 (Selöz) & 15.08.2015 & $40^{\circ} 7^{\prime} 51.45^{\prime \prime} \mathrm{N}$ & $29^{\circ} 55^{\prime} 49.31^{\prime \prime} \mathrm{E}$ & G.p.p. \\
\hline 86 & Hamsu Creek-3 (Ulupınar) & 15.08 .2015 & $40^{\circ} 7^{\prime} 15.06^{\prime \prime} \mathrm{N}$ & $29^{\circ} 53^{\prime} 15.29^{\prime \prime} \mathrm{E}$ & G.p.p. \\
\hline 87 & Fountain (Ulupınar) & 15.08 .2015 & $40^{\circ} 6^{\prime} 39.34^{\prime \prime} \mathrm{N}$ & $29^{\circ} 52^{\prime} 59.33^{\prime \prime} \mathrm{E}$ & G.p.p. \\
\hline 88 & Fountain (Karadede) & 15.08 .2015 & $40^{\circ} 5^{\prime} 12.68^{\prime \prime} \mathrm{N}$ & $29^{\circ} 50^{\prime} 49.86^{\prime \prime} \mathrm{E}$ & G.p.p. \\
\hline 89 & Günyurdu Creek & 15.08 .2015 & $40^{\circ} 4^{\prime} 32.17^{\prime \prime} \mathrm{N}$ & $29^{\circ} 50^{\prime} 27.55^{\prime \prime} \mathrm{E}$ & G.p.p. \\
\hline 90 & Fountain (Büyükelmalı) & 15.08 .2015 & $40^{\circ} 3^{\prime} 9.11^{\prime \prime} \mathrm{N}$ & $29^{\circ} 48^{\prime} 25.90^{\prime \prime} \mathrm{E}$ & G.u. \\
\hline 91 & Fountain (Küplü Bridge) & 5.12 .2015 & $40^{\circ} 00^{\prime} 36.118^{\prime \prime} \mathrm{N}$ & $30^{\circ} 39^{\prime} 54.38^{\prime \prime} \mathrm{E}$ & G.an. \\
\hline 92 & Küplü Creek (Mayıslar) & 5.12 .2015 & $40^{\circ} 01^{\prime} 29.168^{\prime \prime} \mathrm{N}$ & $30^{\circ} 39^{\prime} 16.609^{\prime \prime} \mathrm{E}$ & G.an. \\
\hline 93 & Sorgun Creek & 5.12 .2015 & $40^{\circ} 20^{\prime} 24.34^{\prime \prime} \mathrm{N}$ & $31^{\circ} 14^{\prime} 22.44^{\prime \prime} \mathrm{E}$ & G.p.p. \\
\hline 94 & Mudurnu Stream-1 & 5.12 .2015 & $40^{\circ} 31^{\prime} 26.641^{\prime \prime} \mathrm{N}$ & $31^{\circ} 14^{\prime} 33.935^{\prime \prime} \mathrm{E}$ & G.p.p. \\
\hline 95 & Dere-1 (Uğurköy) & 6.12 .2015 & $40^{\circ} 44^{\prime} 3.294^{\prime \prime} \mathrm{N}$ & $31^{\circ} 12^{\prime} 51.735^{\prime \prime} \mathrm{E}$ & G.k. \\
\hline 96 & Dere-2 (Uğurköy) & 6.12 .2015 & $40^{\circ} 44^{\prime} 16.807^{\prime \prime} \mathrm{N}$ & $31^{\circ} 12^{\prime} 28.224^{\prime \prime} \mathrm{E}$ & G.ar. \\
\hline 97 & Creek (Gelenöz) & 6.12 .2015 & $40^{\circ} 55^{\prime} 57.80^{\prime \prime} \mathrm{N}$ & $31^{\circ} 19^{\prime} 38.43^{\prime \prime} \mathrm{E}$ & G.k. \\
\hline 98 & Creek (Ahmetçiler) & 6.12 .2015 & $40^{\circ} 58^{\prime} 33.194^{\prime \prime} \mathrm{N}$ & $31^{\circ} 26^{\prime} 5.346^{\prime \prime} \mathrm{E}$ & G.k. \\
\hline 99 & Creek (Tıraşlar) & 6.12 .2015 & $41^{\circ} 00^{\prime} 37.326^{\prime \prime} \mathrm{N}$ & $31^{\circ} 24^{\prime} 52.136^{\prime \prime} \mathrm{E}$ & G.k. \\
\hline 100 & Edilli Creek & 8.12 .2015 & $41^{\circ} 4^{\prime} 15.00^{\prime \prime} \mathrm{N}$ & $31^{\circ} 4^{\prime} 18.05^{\prime \prime} \mathrm{E}$ & G.k. \\
\hline 101 & Karaburun Creek & 8.12 .2015 & $41^{\circ} 4^{\prime} 12.32^{\prime \prime} \mathrm{N}$ & $31^{\circ} 1^{\prime} 0.14^{\prime \prime} \mathrm{E}$ & G.k. \\
\hline 102 & Akçay Stream & 8.12 .2015 & $40^{\circ} 34^{\prime} 54.58^{\prime \prime} \mathrm{N}$ & $30^{\circ} 45^{\prime} 19.88^{\prime \prime} \mathrm{E}$ & G.u. \\
\hline 103 & Fountain (Çamyurdu) & 8.12 .2015 & $40^{\circ} 35^{\prime} 32.50^{\prime \prime} \mathrm{N}$ & $30^{\circ} 56^{\prime} 16.35^{\prime \prime} \mathrm{E}$ & G.b. \\
\hline 104 & Çağşak Creek & 9.12 .2015 & $40^{\circ} 33^{\prime} 2.03^{\prime \prime} \mathrm{N}$ & $31^{\circ} 0^{\prime} 17.27^{\prime \prime} \mathrm{E}$ & G.p.p. \\
\hline 105 & Fountain (Tosunlar) & 9.12 .2015 & $40^{\circ} 33^{\prime} 1.99^{\prime \prime} \mathrm{N}$ & $31^{\circ} 0^{\prime} 17.74^{\prime \prime} \mathrm{E}$ & G.p.p. \\
\hline 106 & Gök Dere-1 (Çavuşdere) & 9.12 .2015 & $40^{\circ} 30^{\prime} 7.26^{\prime \prime} \mathrm{N}$ & $31^{\circ} 2^{\prime} 45.90^{\prime \prime} \mathrm{E}$ & G.p.p. \\
\hline 107 & Gök Dere-2 (Yeşilyazı) & 9.12 .2015 & $40^{\circ} 27^{\prime} 20.19^{\prime \prime} \mathrm{N}$ & $30^{\circ} 58^{\prime} 11.10^{\prime \prime} \mathrm{E}$ & G.ar. \\
\hline 108 & Gök Dere-3 (Sünnet) & 9.12 .2015 & $40^{\circ} 26^{\prime} 31.63^{\prime \prime} \mathrm{N}$ & $30^{\circ} 57^{\prime} 38.21^{\prime \prime} \mathrm{E}$ & G.p.p. \\
\hline 109 & Hebirler Creek & 9.12 .2015 & $40^{\circ} 18^{\prime} 49.69^{\prime \prime} \mathrm{N}$ & $30^{\circ} 51^{\prime} 22.56^{\prime \prime} \mathrm{E}$ & G.p.p. \\
\hline 110 & Gelinkaya Creek & 25.04.2016 & $39^{\circ} 18^{\prime} 56.44^{\prime \prime} \mathrm{N}$ & $29^{\circ} 58^{\prime} 39.10^{\prime \prime} \mathrm{E}$ & G.p.p. \\
\hline 111 & Fountain (Yaylaköy) & 25.04 .2016 & $39^{\circ} 5^{\prime} 22.39^{\prime \prime} \mathrm{N}$ & $29^{\circ} 28^{\prime} 15.68^{\prime \prime} \mathrm{E}$ & G.u. \\
\hline 112 & Fountain (Akçaalan) & 25.04.2016 & $39^{\circ} 4^{\prime} 13.56^{\prime \prime} \mathrm{N}$ & $29^{\circ} 24^{\prime} 11.96^{\prime \prime} \mathrm{E}$ & G.u. \\
\hline 113 & Fountain (Aşağıyoncaağaç) & 25.04 .2016 & $39^{\circ} 13^{\prime} 54.39^{\prime \prime} \mathrm{N}$ & $29^{\circ} 14^{\prime} 47.00^{\prime \prime} \mathrm{E}$ & G.u. \\
\hline 114 & Creek (Emet) & 25.04 .2016 & $39^{\circ} 20^{\prime} 14.72^{\prime \prime} \mathrm{N}$ & $29^{\circ} 17^{\prime} 31.51^{\prime \prime} \mathrm{E}$ & G.g. \\
\hline 115 & Fountain (Oysu) & 26.04 .2016 & $38^{\circ} 58^{\prime} 1.80^{\prime \prime} \mathrm{N}$ & $29^{\circ} 54^{\prime} 54.70^{\prime \prime} \mathrm{E}$ & G.g. \\
\hline 116 & Fountain (Saraycık) & 26.04 .2016 & $38^{\circ} 59^{\prime} 4.10^{\prime \prime} \mathrm{N}$ & $29^{\circ} 50^{\prime} 53.30^{\prime \prime} \mathrm{E}$ & G.an. \\
\hline 117 & Banaz Stream-1 & 27.04 .2016 & $38^{\circ} 22^{\prime} 0.87^{\prime \prime} \mathrm{N}$ & $29^{\circ} 19^{\prime} 40.89^{\prime \prime} \mathrm{E}$ & G.an. \\
\hline 118 & Creek (Kıranyer) & 28.04.2016 & $37^{\circ} 48^{\prime} 19.30^{\prime \prime} \mathrm{N}$ & $28^{\circ} 48^{\prime} 37.80^{\prime \prime} \mathrm{E}$ & G.u. \\
\hline 119 & Bozüyük Pınarbaşı Creek & 29.04.2016 & $37^{\circ} 17^{\prime} 44.68^{\prime \prime} \mathrm{N}$ & $28^{\circ} 7^{\prime} 39.24^{\prime \prime} \mathrm{E}$ & G.b. \\
\hline 120 & Banaz Stream-2 & 12.05 .2016 & $38^{\circ} 32^{\prime} 58.12^{\prime \prime} \mathrm{N}$ & $29^{\circ} 37^{\prime} 26.00^{\prime \prime} \mathrm{E}$ & G.p.p. \\
\hline 121 & Hamam Creek & 12.05 .2016 & $38^{\circ} 46^{\prime} 43.20^{\prime \prime} \mathrm{N}$ & $29^{\circ} 49^{\prime} 11.90^{\prime \prime} \mathrm{E}$ & G.p.p. \\
\hline 122 & Dere (Zafertepeçalköy) & 12.05 .2016 & $38^{\circ} 56^{\prime} 46.60^{\prime \prime} \mathrm{N}$ & $30^{\circ} 5^{\prime} 20.30^{\prime \prime} \mathrm{E}$ & G.an. \\
\hline 123 & Çitalan Creek & 17.04.2018 & $39^{\circ} 24^{\prime} 5.30^{\prime \prime} \mathrm{N}$ & $27^{\circ} 36^{\prime} 26.20^{\prime \prime} E$ & G.g. \\
\hline 124 & Yağcılı Creek & 18.04.2018 & $39^{\circ} 14^{\prime} 15.07^{\prime \prime} \mathrm{N}$ & $27^{\circ} 31^{\prime} 56.03^{\prime \prime} \mathrm{E}$ & G.g. \\
\hline 125 & Karina Lagoon & 20.12.2018 & $37^{\circ} 37^{\prime} 13.18^{\prime \prime} \mathrm{N}$ & $27^{\circ} 11^{\prime} 54.00^{\prime \prime} \mathrm{E}$ & G.ae. \\
\hline 126 & Tuzburgazı Spring & 20.12.2018 & $37^{\circ} 37^{\prime} 15.88^{\prime \prime} \mathrm{N}$ & $27^{\circ} 11^{\prime} 54.46^{\prime \prime} \mathrm{E}$ & G.ae. \\
\hline 127 & Creek (Soğanlı) & 16.03.2019 & $38^{\circ} 32^{\prime} 7.20^{\prime \prime} \mathrm{N}$ & $28^{\circ} 26^{\prime} 8.92^{\prime \prime} \mathrm{E}$ & G.p.p. \\
\hline
\end{tabular}

ally, the basis of the pereiopod VII bears few setae on the posteroventral side. The main and accessory flagellum of antenna I consist of 21-25 and 3-4 segments, respectively. The flagellum of antenna II consists of 11-13 segments; with few flag-like brush setae on the posterior margins. Calceoli can be present or absent. The third segment of the mandibular palp bears 1 group of A-setae, 1 group of B-setae, 23-25 D-setae, and 4-5
E-setae. C-setae is absent. Pereiopod III and IV have a weak setation. Pereiopods V-VII bears the only spine on the anterior margin in segments 3-6, the setae is usually absent, if there is any, it is shorter than the spines. Rami of the uropod III is weakly armed. Telson lobes are cleft and more than twice their width. Each lobe has 2-3 spines and 4-5 setae on the terminal and usually 2 plumose setae on the lateral margin. 
Examined material: St. 91: 5 ९९, 10 ơ $^{*}, 5 . x i i .2015 ;$ St. 92: 9 \%९, 18 ơ $^{\prime \prime}$, 5.xii.2015; St. 115: 28 ㅇ, 34 o" o", 26.iv.2016; St. 116: 6 ㅇ, 7

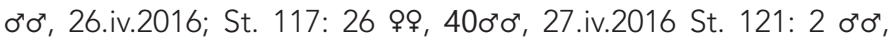

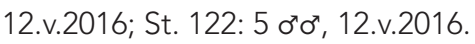

G. arduus: The body length is $14-15 \mathrm{~mm}$ in adults. Within the Gammarus pulex-group, it can be easily distinguished from the others by the antenna II that has a slender flagellum, and the epimeral plate II bears densely setae on the outer surface and distal margin, and especially basis of the pereiopod VI-VII bear setae on the postero-ventral side. Sometimes segments of the metasome II and III bear setae on the dorsal margin. Peduncles of the antenna I have a weak setation like flagellum. The main and accessory flagellum consists of 26-30 and 3-5 segments, respectively. Calceoli is absent. The third segment of mandibular palp bears 1 group of A-setae, 2 groups of B-setae, 25-27 D-setae, and 4-6 E-setae. C-setae is absent. Pereiopod III and IV are slender and have short dactylus. Epimeral plates I-III can be slightly pointed on the posterodistal corner. Epimeral plate II with numerous setae on the outer surface. The Rami of uropod III has many simple and plumose setae. The telson lobes are deeply cleft and about 3 times their width.

Examined material: St. 24: 28 \%я, $290^{\pi} \sigma^{\pi}$, 31.vii.2015; St. 25: 52 \%ᄋ, $52 \sigma^{7} \sigma^{\prime \prime}, 31 . v i i .2015 ;$ St. 26: 49 우, $57 \sigma^{\prime} \sigma^{\prime \prime}, 1 . v i i i .2015$; St. $27: 29$ ㅇ, $32 \sigma^{\top} \sigma^{\prime \prime}, 1$.viii.2015; St. 28: 37 o\%, $37 \sigma^{\top} \sigma^{*}, 1$.viii.2015; St. 29: 21 \&ᄋ, 26 ơ ơ, 2.viii.2015; St. 30: 43 \%q, 84 ơ ơ, 2.viii.2015; St. 32: 15 \%o, 21

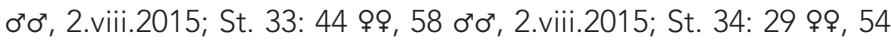
ơ ơ, 3.viii.2015; St. 35: 14 \%ᄋ, 35 ơ ơ, 3.viii.2015; St. 36: 23 фo, 66

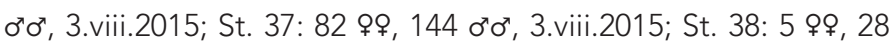
ơ ơ, 3.viii.2015; St. 40: 61 \%ᄋ, 68 ơ o', 3.viii.2015; St. 41: 43 \%ᄋ, 68 $\sigma^{7} \sigma^{\prime \prime}, 3 . v i i .2015 ;$ St. 42: 46 ᄋq, $57 \sigma^{x} \sigma^{x}$, 4.viii.2015; St. 43: 21 \%ᄋ, 29

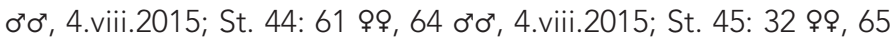
ơ $^{x}$, 4.viii.2015; St. 46: 60 \%ᄋ, 83 ơ ơ, 4.viii.2015; St. 47: 10 \%ᄋ, 24 $\sigma^{\top} \sigma^{\prime \prime}, 5 . v i i i .2015$; St. 48: 14 oq, $11 \sigma^{\top} \sigma^{\prime \prime}$, 5.viii.2015; St. 50: 28 \%ᄋ, 124

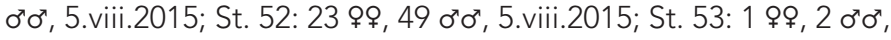

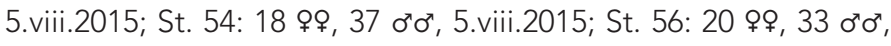
6.viii.2015; St. 61: 18 \%o, 28 ơ o', 6.viii.2015; St. 62: 13 \%ᄋ, 46 ơ o', 7.viii.2015; St. 63: $12 \sigma^{\pi} \sigma^{\pi}$, 7.viii.2015; St. 96: 10 \%क, $55 \sigma^{\pi} \sigma^{\pi}$, 6.xii.2015;

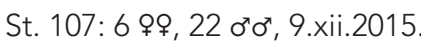

G. balcanicus: The maximum body length is about $12-13 \mathrm{~mm}$ in adults, a relatively small species. The antenna II is slender and has fewer setae. The pereiopods III-IV bear a few short setae, the pereiopods V-VII bear almost no seta, if any seta is present, it is always shorter than the spines. Epimeral plates I-III can be slightly pointed on the posterodistal corner and bear the only spine. The antenna I has a weak setation; the main and accessory flagellum consists of 21-25 and 3-4 segments, respectively. Antenna II bears short and fewer setae. The flagellum consists of 10-14 segments; the length of the setae is shorter than the diameter of the segments on which they are implanted. Calceoli can be present or absent. The third segment of the mandibular palp bears 2 groups of A-setae, 1 group of B-setae, 22-26 D-setae, and 4-5 long E-setae. C-setae is absent. Gnathopod I and II bear a small numerous of setae. The rami of uropod III bears only simple setae on both margins; there are no plumose setae. The telson lobes are deeply cleft and about 2 times their width.

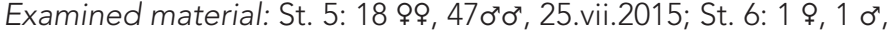
25.vii.2015; St. 7: 10 ㅇ, 22 o' $\sigma^{\prime \prime}$ 25.vii.2015; St. 8: 21 ㅇ, 17 ơ $\sigma^{\prime \prime}$

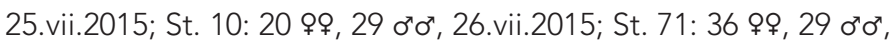
10.viii.2015; St. 82: 10 우, $11 \sigma^{7} \sigma^{x}$, 14.viii.2015; St. 102: $6 \sigma^{\pi} \sigma^{\prime \prime}$, 8.xii.2015; St. 103: 29 ᄋᄋ, 42 ơ ơ', 8.xii.2015; St. 119: 49 ९ᄋ, 62 ơ o', 29.iv.2016.

G. dorsosetosus: The body is smooth and its length is up to 10$11 \mathrm{~mm}$ in adults. Within the Gammarus balcanicus-group, it can be easily distinguished from the others by the presence of long setae on the dorsoposterior margin of the metasome segments, which is a distinguishing morphological character for these species. The antenna I has a weak setation and the main and accessory flagellum consists of $20-23$ and 2 segments, respectively. Antenna II bears fewer setae. The flagellum consists of 11 segments. Calceoli is absent. The third segment of mandibular palp bears one group of A-setae, one group of B-setae, 23-24 D-setae, and 4-5 E-setae. C-setae is absent. The lengths of pereiopod $\mathrm{V}$-VII are almost the same, the length of the basis is 1.5 times their width, but the pereiopod $V$ is relatively quadrangular in form and slightly longer than the width. The endopodite of the uropod III is about as long as 3/5 of the exopodite; the rami bear some plumose setae. The telson lobes are cleft and about 2.5 times their width.

Examined material: St. 81: 5 ㅇ, $16 \sigma^{\pi} \sigma^{\prime \prime}, 14$. viii.2015; St. 84 : 7 \%ᄋ,

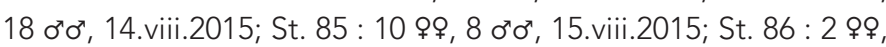
11 ơం $^{\pi}, 15 . v i i i .2015 ;$ St. 93: 2 ơం $^{\top}, 5 . x i i .2015$.

G. gonensis: The body is smooth, medium to large, and up to 13$14 \mathrm{~mm}$ in adults. It belongs to the Gammarus pulex-group and is similar to Gammarus uludagi except for bearing many setae along the anterior margins of pereiopods 5-7, bearing less setose on the peduncle segments of the antenna II, bearing more setae on the propodus of the gnathopod II and having longer antenna I. The main and accessory flagellum of antenna I consist of 30 and 4 segments, respectively. Peduncles and flagellum have a weak setation. The flagellum of antenna II consists of 11 slightly swollen segments. Calceoli present on the segments 1-7. The third segment of the mandibular palp bears 1 group of A-setae, 2 groups of B-setae, 29 D-setae, and 6 E-setae. C-setae is absent. Endopodite of the uropod III is about as long as 3/4 of the exopodite with numerous plumose setae on both margins. The telson lobes are deeply cleft and about 2.5 times their width.

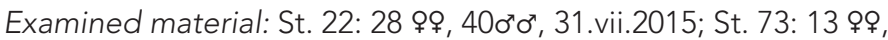
$11 \sigma^{x} \sigma^{\prime \prime}, 11$. viii.2015; St. 77 : 5 oᄋ, 13 ơ ơ, 13.viii.2015; St. 78 : 6 o\%, $41 \sigma^{\top} \sigma^{\prime \prime}, 13 . v i i i .2015 ;$ St. 114: 24 \%o, 41 ơ $^{\pi}$, 25.iv.2016; St. 115: 5 \%ᄋ, $11 \sigma^{\top} \sigma^{\prime \prime}, 26 . i v .2016$; St. 123: 18 oᄋ, 15 ơ o', 17.iv.2018; St. 124: 19 \%ᄋ, $23 \sigma^{x} \sigma^{\prime \prime}, 18 . i v .2018$.

G. komareki: The body is smooth, medium to large, and up to $15 \mathrm{~mm}$ in adults. It belongs to the Gammarus pulex-group and the most distinguishing morphological character is that the peduncles and flagellum of the antenna II have a very densely and long setation. The antenna I has a weak setation. There is Metasome III with some spinules on the dorsoposterior margin. The antenna I is long and as long as 2/3 of the total body length. Peduncles and flagellum have a weak setation. The main and ac- 
cessory flagellum consists of 35-38 and 4-5 segments, respectively. The second and third peduncles and flagellum segments of the antenna II have a very dense, long and curled setation. The transverse rows of setae of the flagellum are 3 times the diameter of the segment on which they are implanted. The flagellum consists of 13 slightly swollen segments. Calceoli is absent. The third segment of the mandibular palp bears 1 group of A-setae, 1-2 groups of B-setae, 35 D-setae, and 4-6 E-setae. C-setae is absent. The endopodite of the uropod III is about as long as 3/4 of the exopodite; rami with some spines and numerous plumose setae on both margins. The telson lobes are deeply cleft and about as long as twice their width.

Examined material: St. 31: 37 oq, 55 ơ or, 2.viii.2015; St. 32: 47 oq, 44

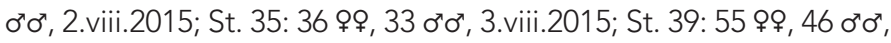

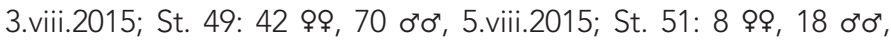

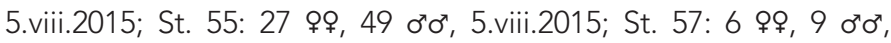

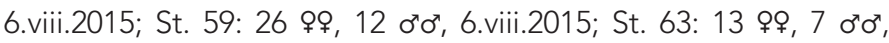

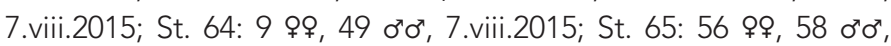

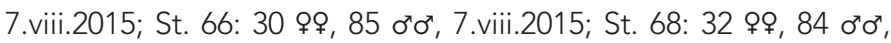

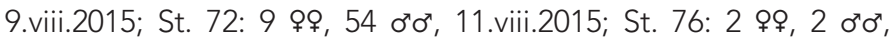

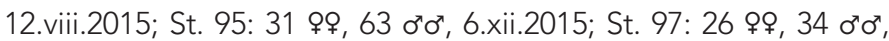

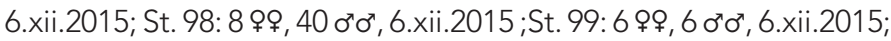

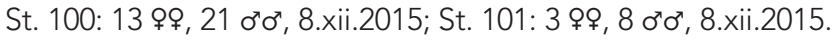

G. lacustris: The body is smooth and large and up to $24 \mathrm{~mm}$ in adults. It belongs to the Gammarus pulex-group and is similar to Gammarus pulex pulex except for bearing not flag-like brush setae, it has relatively short and slender antennae, has more sharply pointed Epimeral plates, and slender dactylus. Metasome II and III with some spinules on the dorsoposterior margin. The antenna I is relatively short and slightly exceeds $1 / 3$ of the total body length. The Peduncles and flagellum have a weak setation. The main and accessory flagellum consists of 27 and 3-4 segments, respectively. The fourth and fifth peduncles of the antenna II are almost equal in length with few setae, implanted in 3-4 longitudinal rows. Calceoli is present. There is no calceoli in some periods of the year as given information in the literature. The third segment of the mandibular palp bears 1 group of A-setae, 1 group of B-setae, $27 \mathrm{D}$-setae, and $4 \mathrm{E}$-setae. C-setae is absent. Endopodite of the uropod III reaches about 3/4 of the exopodite; rami with numerous plumose setae. The telson lobes are cleft and about as long as three their width.

\section{Examined material: St. 67: 40 oq, 73 ơ $^{\pi}$, 9.viii.2015}

G. pulex pulex: The body is smooth and large and is up to 25$30 \mathrm{~mm}$ in adults. The Antenna II with a swollen compressed flagellum bears flag-like brush setae on the posterior margin; the swollen and compressed flagellum consists of 11-12 segments; each segment bears a transverse row of setae; Peduncles and flagellum of antenna I have a weak setation. The main and accessory flagellum consists of 25 and 5 segments, respectively. Calceoli is absent or present. The third segment of the mandibular palp bears 1 group of A-setae, 1 group of B-setae, 28 D-setae, and 5 E-setae. C-setae is absent. Pereiopods III-IV with long and curled setae. Rami of uropod III has a dense setation. The telson lobes are deeply cleft and about as long as three their width.

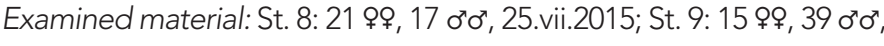
26.vii.2015; St. 10: 9 \%ᄋ, 17 ơ ơ, 26.vii.2015; St. 58 : 45 фo, 50 ơ ơ,

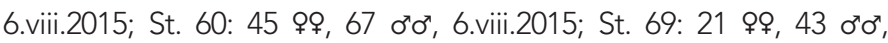

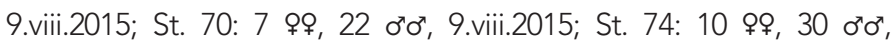

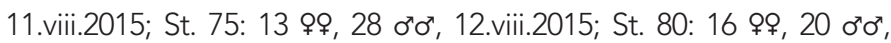
13.viii.2015; St. 81: 7 q , $4 \sigma^{\prime \prime} \sigma^{\prime \prime}$, 14.viii.2015; St. 83: 1 \&, $1 \sigma^{\prime \prime} \sigma^{\prime \prime}$, 14.viii.2015;

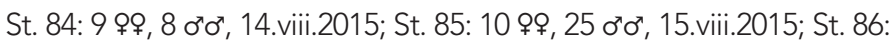

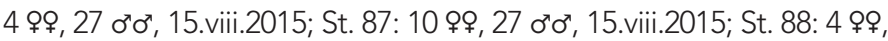

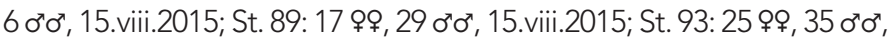

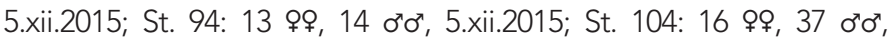

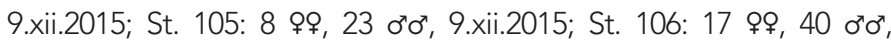

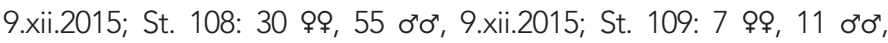
9.xii.2015; St. 110: 17 ㅇ, 23 ơ $^{\pi}$, 25.iv.2016; St. 116: 15 우, 17 б $\sigma^{\pi}$,

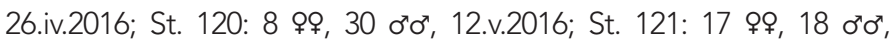
12.v.2016; St. 122: 17 ㅇ, 23 ơ ơ, 12.v.2016; St. 127: 3 워, 1 ơ', 16.iii.2019.

G. uludagi: The body smooth and medium-large is $13 \mathrm{~mm}$ in adults. It is very similar to $G$. fossarum and $G$. gonensis at first sight, but it has flag-like brush setae on the flagellum of the antenna II and long setae on the peduncle segments. The fourth and fifth peduncles are almost equal in length and bear 4-5 groups of long setae with transverse rows on the posterior margin and these setae are about as long as or longer than the diameter of the segments on which are implanted. The swollen and compressed flagellum of antenna II consists of 11-12 segments; each segment bears a transverse row of setae. With a very characteristic feature, the telson lobes are deeply cleft and longer than twice their width. Each lobe has 2-3 groups of setae and 2 short plumose setae on the outer lateral margin, 2-3 groups of setae on the inner lateral margin, and additionally to 1 spine and 4-5 setae on the terminal; these setae are about as long as or longer than the length of the lobes. Peduncles and flagellum of antenna I have a weak setation. The main and accessory flagellum consists of 32 and 6 segments, respectively. Calceoli is absent. The third segment of the mandibular palp bears 1 group of A-setae, 1 group of B-setae, 27 D-setae, and 6 E-setae. C-setae is absent. Endopodite of the uropod III is about as long as $3 / 5$ of the exopodite; The rami bear simple setae on both margins.

Examined material: St. 1: 18 ९q, 20 ơ ơ, 12.v.2014; St. 4 : 27 ९ᄋ, 42

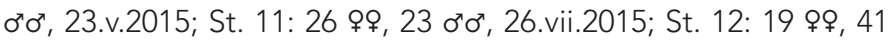
ơ ơ, 27.vii.2015; St. 13: 16 \%q, 71 ơ o', 27.vii.2015; St. 14: 26 ९q, 42 $\sigma^{\prime \prime} \sigma^{\prime \prime}, 27 . v i i .2015$; St. 15: 21 oq, 43 ơ o", 27.vii.2015; St. 16: 7 \%ᄋ, 59

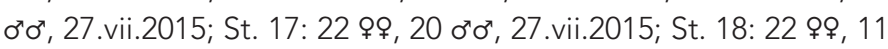

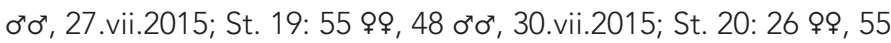
ơ ơ, 30.vii.2015; St. 21: 49 \%ᄋ, 53 ơ ơ, 30.vii.2015; St. 23: 31 \%o, 51

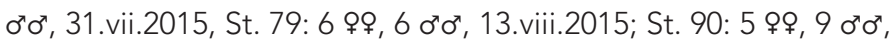
15.viii.2015; St. 102: 3 \%o, $14 \sigma^{7} \sigma^{\prime \prime}$, 8.xii.2015; St. 111: 13 \% , 33 o $\sigma^{\prime \prime}$,

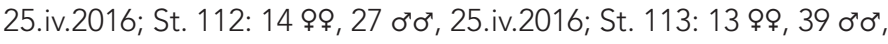
25.iv.2016; St. 118 : 30 \%ᄋ, 40 ơ ơ", 28.iv.2016.

\section{Diagnostic key}

1. a) Endopodite of the uropod III is less than $1 / 4$ of the length of the exopodite .....(Echinogammarus) ............................ ...... Echinogammarus stocki G. Karaman, 1970

b) Endopodite of the uropod III is longer than 1/4 of the length of the exopodite ...............(Gammarus) .............. 2 
2. a) Eyes elongated, kidney-shaped

Gammarus aequicauda

(Martynov,

b) The eyes are round or oval

3. a) Posterior margins of the pereiopod III-IV poorly setose...........(Gammarus balcanicus-group).

b) Pereiopod III-IV with numerous long setae......... (Gammarus pulex-group)

\section{6}

4. a) Inner surface of basal segment of the pereiopod VII with setae...... Gammarus anatoliensis Schellenberg, 1937

b) Inner surface of basal segment of the pereiopod VII with out setae

5. a) Metasome segments with a few long setae on dorsoposterior margins.......................................... Gammarus dorsosetosus Mateus \& Mateus, 1990

b) Metasome segments without long setae on dorsoposterior margins

Gammarus balcanicus Schäferna, 1923

6. a) Inner surface of basal segment of the pereiopod VI-VII with setae ................................................. Gammarus $\begin{array}{llll}\text { arduus } & \text { G. Karaman, } & 1975\end{array}$

b) Inner surface of basal segment of the pereiopod VI-VII without setae

7. a) Peduncle and flagellum segments of antenna II densely set with brushes of very long setae ................................................. Gammarus komareki

Schäferna, 1923

b) Peduncle and flagellum segments of antenna II with shorter setae

8. a) Inner surface of palm of the gnathopod II with many long curled setae

b) Inner surface of palm of the gnathopod II without curled setae

9. a) Peduncles of the antenna II bear long setae (as long as or longer than the diameter of the segments)

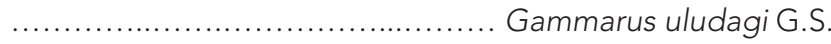
Karaman, 1975

b) Peduncles of the antenna II with short setae ........ Gammarus gonensis Özbek, 2016

10. a) Flagellar segments of antenna II swollen bearing flag like setae. Epimeral plate II-III with rectangular to weekly pointed .................. Gammarus pulex pulex (Linnaeus, 1758)

b) Flagellar segments of antenna II without flag like setae. Epimeral plate II-III with sharply pointed posteroinferior corners ................... Gammarus lacustris G.O. Sars, 1863
E. stocki is one of the most difficult species to find because it inhabits a very narrow zone on the verge of freshwater and brackish or marine waters as stated in the literature (Pinkster, 1993). The type locality of the species is a salt spring in Cres Island (Karaman, 1970). In Turkey, it was firstly recorded from the Bafa Lake by Karaman (1971). Then, several recordings were reported from the lake (Geldiay et al., 1977; Kocataş \& Katağan, 1978; Bellan-Santini et al., 1982; Ustaoğlu et al., 1998; Sarı et al., 2001). In this study, the species was reported from a spring in the Ekinanbarı village for the first time. The species was previously confused with E. acarinatus, then Karaman (1970) eliminated this confusion when he revealed the presence of C-seta in the mandibular palp which is an important character distinguishing it from the other Echinogammarus species. Although it was stated that the sample from France has setae on the anterior margin of the epimeral plate I and the ventral margins of the epimeral plates II-III (Pinkster, 1993), these setae were absent in our samples (Figure 2).

The type locality of $G$. aequicauda is Donuzlav Lake in Crimea. In Turkey, it was firstly recorded from a brackish water pool in Mersin province by Stock (1967). The species is abundant, especially in Western Anatolia (from Çanakkale to Muğla provinces) and there are several records from Mersin and Antalya in the Mediterranean, Sinop and Samsun in the Black Sea, Çanakkale, Edirne and Istanbul in Thrace region (Altınsaçlı et al., 2017; Akbulut et al., 2002, 2009a, 2009b; Balık et al., 2006; Bat et al., 2000; Karaman, 2003, Kocataş \& Katağan, 1978; Mateus \& Mateus, 1990; Özbek 2011; Özbek \& Ustaoğlu, 1998, Özbek et al., 2015, 2016; Sarı et al., 2001; Ustaoğlu et al., 1998, 2000). It was also reported from the Gökçeada Island (Aegean Sea) (Özbek \& Özkan, 2017). Considering the morphological features of $G$. aequicauda given in the literature, the brackish water forms reported from Crimea and Mersin look similar, while the freshwater form from southern France has weaker setation than the others (Stock, 1967). The samples we studied are similar to those recorded from the Mersin province in terms of the length of the base of pereiopods V-VII. On the other hand, the present specimens differ from those reported from southern France in terms of the length of the basal segments of pereiopods V-VII and the setation of the anterior margins of the mentioned segments (Figure 2).

The type locality of $G$. anatoliensis is a torrent in Akşehir, Konya (Schellenberg, 1937). It is an endemic species of Turkey. G. anatoliensis is widespread in the Lake District Region of Turkey, but it was also recorded from the Marmara, the Black Sea, the Aegean, and the Mediterranean regions of Turkey (Karaman \& Pinkster, 1987, Özbek \& Ustaoğlu, 2005, 2008, 2011; Özbek et al., 2009; Ekinci \& Miroğlu 2016; Ipek et al., 2017). In the present study, the species was recorded from the Uşak province for the first time. G. anatoliensis was detected at 7 localities in our study. The present specimens are almost identical with Karaman and Pinkster's (1987) description, but some variations were also observed (such as the absence of calceoli).

The type locality of $G$. arduus is a fountain in Malkara, Tekirdağ (Karaman 1975) in Turkey. The species was also recorded from the Ordu and Samsun provinces in the Black Sea Region of Turkey (Chertoprud \& Palatov, 2017; Gözal, 2004; Karaman \& Pinkster, 1977; Mateus \& Mateus, 1990; Karaman, 2003; Özbek et al., 


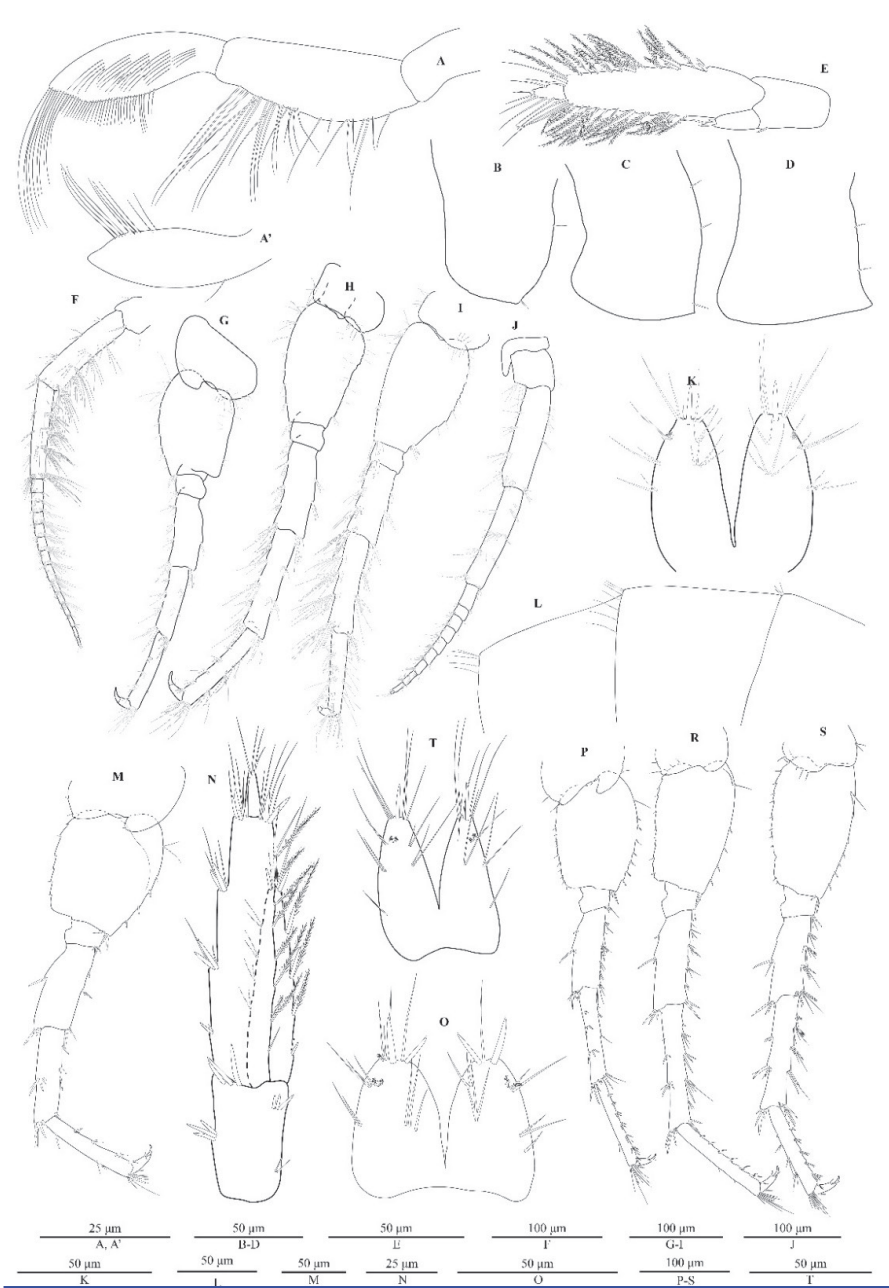

Figure 2. Some extremities (original) of E. stocki (A-E) (St.2), G. aequicauda (F-I) (St.2), G. arduus (J-K) (St.62), G dorsosetosus (L-N) (St.93), G. komareki (O-S) (St.31), G. lacustris (T) (St.67). Male. A: mandibular palp; A': inner surface of the third segment of mandibular palp; B: epimeral plate I; C: epimeral plate II; D: epimeral plate III; E: uropod III; F: antenna II; G: pereiopod $\mathrm{V}$; $\mathrm{H}$ : pereiopod $\mathrm{VI}$; I: pereiopod $\mathrm{VII}$; J: antenna II; K: telson; L: metasoma somites I-III; M: pereiopod $\mathrm{V}$; N: uropod III; O: telson; P: pereiopod $\mathrm{V}$; R: pereiopod VI; S: pereiopod VII; T: telson.

2017; Özkan, 2009; Yeşilmen \& Kırgız, 1996). In this study, the species was reported from Bolu and Düzce provinces for the first time. The specimens examined in this study have no calceoli.

The type locality of $G$. balcanicus is a spring in Kolašin, Montenegro (Schäferna, 1923). In Turkey, it was first recorded from the Erciyes Mountain by S. Karaman (1934). Then, it was reported from several localities from the Strandja Mountains in Thrace to Bayburt in the Black Sea region, from Izmir in the Aegean to Hatay on the Mediterranean coast and to Van in eastern Anatolia (Akbulut et al., 2009b; Akbaba \& Boyacı, 2015; Aygen \& Balık, 2005; Balık et al., 2006; Baytaşoğlu \& Gözler, 2018; Chertoprud \& Palatov, 2017; Ekinci \& Miroğlu, 2016; İpek \& Şirin, 2009; İpek et al.,
2017; Karaman, 2003, Karaman \& Pinkster, 1987; Öntürk \& Ipek, 2018; Özbek \& Ustaoğlu, 2005, 2008, 2011; Özbek et al., 2004, 2009; Ustaoğlu et al., 2004, 2008). In this study, the species was recorded from the Kocaeli and Sakarya provinces for the first time.

Karaman and Pinkster (1987) showed that the species has calceoli on the flagellum of the antenna II, but they mentioned that it is a variable character. Calceoli is also absent in our samples. The wide distribution of the species and its presence in various environments indicate the high tolerance of the species, as mentioned by Karaman and Pinkster (1987).

The type locality of $G$. dorsosetosus is the Amanos Mountains, Hatay province (Mateus \& Mateus, 1990), and it is an endemic species for Turkey. The species was also reported from the Burdur and Karaman provinces (Özbek \& Topkara, 2007). In this study, the first record of the species from the Bolu province is documented. The slightly elevated metasome segments and the presence of long setae on the dorsoposterior margins are the characteristic features of the species (Figure 2). Mateus and Mateus (1990) did not provide detailed drawings of this species. However, Özbek and Topkara (2007) gave detailed drawings of the morphological characteristics of this species.

The type locality of Gammarus gonensis is the Gönen Stream in Balıkesir (Özbek 2016). It was also recorded from Çanakkale, and Tekirdağ (Özbek et al., 2017), Kütahya (İpek et al., 2017) provinces. In this study, the species was firstly recorded from the Istanbul (in Thrace), and Manisa provinces. G. gonensis is similar to the G. uludagi however, it can be easily distinguished from G. uludagi by the absence of long setae on the peduncle segments of antenna II, and by the presence of densely and curved setae on the inner surface of the propodus of the gnathopod II. In our study, the species was determined as a result of sampling made among the stones on the ground of streams with vegetation as Özbek (2016) stated.

The type locality of G. komareki is in Belovo Village near Pazarzik, Bulgaria (Schäferna, 1923). In Turkey, it was firstly recorded by Karaman (1975) from a fountain in Malkara, Tekirdağ. Although it is mostly located in Thrace in our country, it has records from the Marmara and Black Sea regions in Anatolia (Akbulut et al., 2009b; Aslan et al., 2018; Chertoprud \& Palatov, 2017; Ekinci \& Miroğlu, 2016; Gözal, 2004; Karaman, 1975, 2003; Mateus \& Mateus, 1990; Odabaşı et al., 2016; Özbek, 2008, 2011; Özbek \& Özkan, 2017; Özbek et al., 2017; Yeşilmen \& Kırgız, 1996). By the present study, the species was recorded for the first time from the Düzce and Kocaeli provinces. In the samples we examined, the telson lobes were wider and P5-7 were without long setae on the anterior margins. We omitted it as it is a variation (Figure 2).

The type locality of $G$. lacustris is Scandinavia (Sars, 1863) was firstly recorded in Turkey by Tareen (1974) from the Gölcük Lake in Izmir. Despite the presence of several records of the species from Anatolia (Karaman, 1975, 2003; Özbek \& Ustaoğlu, 2005, 2011; Özbek \& Ustaoğlu, 1998; Özbek et al., 2007), it was firstly recorded from the Thrace Region of Turkey in the present study. The samples we examined have setae on the telson lobes that 
were absent in Karaman and Pinkster's (1977a) report (Figure 2). Considering the previous studies, the setation of the telson in the samples in Lake Dimon and Venerocolo in Italy and especially in Lake Lame and the Lake District Region (Turkey) is similar to our samples (Ruffo 1951; Özbek \& Ustaoğlu, 2005).

The type locality of G. pulex pulex is in Öland Island, Sweden (Linnaeus, 1758). G. pulex pulex, which gives its name to the $G$. pulex-group and is a typical representative of the group, is one of the members of the genus Gammarus with the greatest distribution in the world. It has a wide distribution in Turkey (Karaman, 1975; Karaman \& Pinkster, 1977; Bat et al., 2000; Akbulut et al., 2002, 2009b; Ekinci \& Miroğlu, 2016; Özbek \& Ustaoğlu, 2005; Özbek et al., 2017). In our study, it was identified from the provinces of Kırklareli in Thrace, and Kocaeli, Sakarya, and Uşak in Western Anatolia for the first time except for the regions previously identified.

The type locality of G. uludagi is the Uludağ Mountain in Bursa (Karaman, 1975). It is an endemic species of Turkey. Also, several records were given from the western parts of Anatolia, the island of Lesbos on the Anatolian coast, and the Black Sea Region of Turkey (Akbulut et al., 2009b; Karaman, 1975; Karaman \& Pinkster, 1977; Özbek \& Ustaoğlu, 1998; Özbek et al., 2015, 2017; Şirin et al., 2009). In the present study, it was firstly recorded from a fountain in the Pasha Plateau on the Aydın Mountains, and Bilecik, and a stream in Sakarya.

\section{CONCLUSION}

In this study, in which amphipod species are distributed in Western Anatolia, Marmara and Thrace regions of Turkey were investigated, a total of 11 species were determined. This study, which aims to support the discovery of Turkish freshwater amphipod biodiversity, can be a resource for native amphipod researchers. It is obvious that rivers and lakes are under adverse conditions due to human pressure and global climate change. Several species living in Turkish rivers and lakes under the threat of pollution and frost are adversely affected by these changes, and some of them are completely eliminated. Under these conditions, the detection of biodiversity and the protection of our biological richness are of great importance. The authors believe that biodiversity studies should be supported and their numbers should be increased. Afterwards, sustainable management strategies can be developed.

Acknowledgements: The first author would like to thank his other co-advisor Prof. Dr. Özgür Emiroğlu for his help to finish the $\mathrm{PhD}$ thesis.

\section{REFERENCES}

Akbaba, G. \& Boyacı, Y. Ö. (2015). The seasonal change of macrobenthic fauna in Işıklı Lake (Denizli). Journal of Egirdir Fisheries Faculty 11(2), 8-19. [in Turkish] [CrossRef]

Akbulut, M., Öztürk, M. \& Öztürk, M. (2002). The benthic macroinvertebrate fauna of Sarıkum lake and spring waters (Sinop). Turkish Journal of Marine Sciences, 8, 103-119.

Akbulut, M., Çelik E. Ş., Odabaşı, D. A., Kaya, H., Selvi, K., Arslan, N. \& Sağır-Odabaşı, S. (2009a). Seasonal distribution and composition of benthic Macroinvertebrate communities in Menderes Creek,
Çanakkale, Turkey. Fresenius Environmental Bulletin, 18(11a), 21362145.

Akbulut, M., Ustaoğlu, M. R. \& Çelik, E.Ş. (2009b). Freshwater and brackishwater Malacostraca (Crustacea-Arthropoda) fauna of Sinop and Samsun. Journal of the Black Sea/Mediterranean Environment, 15(1), 47-60

Altınsaçlı, S., Yardımcı, C. H., Altınsaçlı, S. \& Paçal, F.P. (2017). The species list belonging to some benthic invertebrate groups in a coastal lagoon: Kamil Abduş lagoon (İstanbul, Turkey). Journal of Entomology and Zoology Studies, 5(6), 307-313.

Aslan, H., Gonulal, O., Can-Yilmaz, E., Elipek, B., Baytut, O., Tosunoglu, M. Karabacak, E. \& Kurt, Y. (2018). Species diversity in lentic, lotic, marine and terrestrial biotopes of Gokceada Salt Lake wetland (Canakkale, Turkey). Fresenius Environmental Bulletin, 27(5), 2853-2866.

Aygen, C. \& Balık, S. (2005). Crustacea fauna of Işıklı Lake and springs (Çivril, Denizli). -Ege Journal of Fisheries and Aquatic Sciences, 22(34), 371-375. [in Turkish]

Balık, S., Ustaoğlu, M. R., Özbek, M., Yıldız, S., Taşdemir, A. \& Illhan, A. (2006). Determination of pollution at lower basin of Küçük Menderes River (Selçuk, İzmir) by using macro benthic invertebrates. Ege Journal of Fisheries and Aquatic Sciences, 23(1-2), 61-65 [in Turkish]

Bat, L., Akbulut, M., Çulha, M. \& Sezgin, M. (2000). The macrobenthic fauna of Sırakaraağaçlar Stream flowing into the Black Sea at Akliman, Sinop. Turkish Journal Marine Sciences, 6(1), 71-86.

Baytaşoğlu, H. \& Gözler, A. M. (2018). Seasonal changes of Malacostraca Crustacea fauna of the upper Coruh River basin Bayburt province Turkey and its ecological characteristics. Turkish Journal of Fisheries and Aquatic Sciences, 18(3), 1-9. [CrossRef]

Bellan-Santini, D., Karaman, G., Krapp-Schickel, G., Ledoyer, M., Myers, A.A., Ruffo, S. \& Schiecke, U. (1982). Part | Gammaridea (Acanthonotozomatidae to Gammaridae). In: S. Ruffo (Ed.), The Amphipoda of Mediterranean (pp. 1-364). Memoires de I'Institut Océanographique, Monaco.

Chertoprud, M.V. \& Palatov, D. M. (2017). Stream macrozoobenthic communities of the eastern Balkans. Inland Water Biology, 10(3), 286-295. [CrossRef]

Coleman, C. O. (2003). "Digital inking": How to make perfect line drawings on computers. Organisms Diversity and Evolution, Electronic Supplement 14, 1-14. [CrossRef]

Coleman, C. O. (2006). Substituting time-consuming pencil drawings in arthropod taxonomy using stacks of digital photographs. Zootaxa, 1360, 61-68. [CrossRef]

Coleman, C. O. (2009). Drawing setae the digital way. Zoosystematics and Evolution, 85(2), 305-310. [CrossRef]

Ekinci, M. \& Miroğlu, A. (2016). Study on freshwater Gammaridea (Crustacea, Amphipoda) fauna of Ordu (Turkey). Ordu University Journal of Science and Tecnology, 6(2), 158-169 [in Turkish].

Geldiay, D., Kocataş, A. \& Katağan, T. (1977). The species of Peracarida and Holocarida (Crustacea, Malacostraca) from Bafa Lake. Ege University Journal of the Faculty of Science, Series B, 1(4), 311-318. [in Turkish]

Gözal, S. (2004). Investigations on Gammaridae (Amphipoda) fauna of some running waters in Thrace. MSc Thesis, Eskişehir Osmangazi University, Turkey, 44 p. [in Turkish]

Horton, T., Lowry, J., De Broyer, C., Bellan-Santini, D., Coleman, C. O., Corbari, L., Costello, M. J., Daneliya, M., Dauvin, J.-C., Fišer, C., Gasca, R., Grabowski, M., Guerra-García, J. M., Hendrycks, E., Hughes, L., Jaume, D., Jazdzewski, K., Kim, Y.-H., King, R., ... Zeidler, W. (2021). World Amphipoda database. Available at: http://www. marinespecies.org/amphipoda (accessed 10.20.21)

İpek, M., Özbek, M. \& Şirin, Ü. (2017). A preliminary study on freshwater Amphipods (Crustacea) of Kütahya province. In: 1st International Symposium on Limnology and Freshwater Fisheries Symposium (LIMNOFISH 2017) (pp. 155). Eğirdir, Isparta, Turkey. 
İpek, M. \& Şirin, Ü. (2009). Gammaridea (Crustacea-Amphipoda) records from Eskişehir province and it's near around. Ege Journal of Fisheries and Aquatic Sciences, 26(4), 241-246.

Karaman, G. S. (1970). XXV. prilog poznavanju Amphipoda Kriticka zapazanja o vrstama Echinogammarus acarinatus (S. Kar. 1931) i Echinogammarus stocki n. sp. Poljoprivreda I Sumarstvo, Titograd, 16(1-2), 193-214.

Karaman, G. S. (1971). XXX. Beitrag zur Kenntnis der Amphipoden, Uber einigen Amphipoden aus Griechenland und Kleinasien. Acta Musei Macedonici Scientiarum Naturalium, 12(2), 1-55.

Karaman, G. S. (1975). Gammarus species from Asia Minor (Fam. Gammaridae), (56. Contribution to the knowledge of the Amphipoda). Bolletino del Museo Civico di Storia Naturale di Verona, 1, 311-343.

Karaman, G. S. (2003). New data on some Gammaridean Amphipods (Amphipoda, Gammaridea) from Palearctic (Contribution to the knowledge of the Amphipoda 245). Podgorica, 15, 21-37.

Karaman, G. S. \& Pinkster, S. (1977). Freshwater Gammarus species from Europe, North Africa and adjacent regions of Asia (Crustecea Amphipoda), Part I Gammarus pulex Group and related species. Bijdragen Tot De Dierkunde, 47(1), 1-164. [CrossRef]

Karaman, G. S. \& Pinkster, S. (1987). Freshwater Gammarus species from Europe, North Africa and adjacent regions of Asia (Crustecea Amphipoda), Part III Gammarus balcanicus Group and related species. Bijdragen Tot De Dierkunde, 57(2), 207-260. [CrossRef]

Karaman, S. (1934). Über asiatische Süsswassergammariden. Zoologischer Anzeiger, 106(5-6). 127-134.

Kocataş, A. \& Katağan, T. (1978). Littoral benthic Amphipods on Turkish seas and their distributions. Project No: TBAG-223. TÜBITAK Research Institute for Fundamental Sciences, Ankara, 63 pp. [in Turkish]

Linnaeus, C. (1758). Systema Naturae, per regna tria naturae, secundum classes, ordines, genera, species, cum characteribus, differentiis, synonymis, locis. Editio decima, reformata (10th revised edition). Holmiae: Laurentius Salvius, 824 pp. [CrossRef]

Lowry, J. K. \& Myers, A. A. (2017). A Phylogeny and classification of the Amphipoda with the establishment of the new order Ingolfiellida (Crustacea: Peracarida). Zootaxa, 4265, 1-89. [CrossRef]

Mateus, A. \& Mateus, E. (1990). Etude d'une collection d'amphipodes, specialement du sud-ouest asiatique, du Museum d'Historie Naturelle de Vienne (Autriche). Annales des naturhistorischer Museum Wien, 91B, 273-331.

Odabaşı, S., Odabaşı, D. A., Çakır, F. \& Bal, D. (2016) A preliminary investigation on the lipid content and fatty acid composition of Gammarus komareki (Schaferna 1922), (Crustacea: Amphipoda). Turkish Journal of Aquatic Sciences, 31(2), 59-67. [CrossRef]

Öntürk, T. \& İpek, M. (2018). Investigations on the Eskisehir and its surroundings Amphipoda fauna. International Journal of Environmental Research and Technology, 1(1), 35-41.

Özbek, M. (2008). Malacostraca (Crustacea) fauna of some lakes in western Black Sea region. Ege Journal of Fisheries and Aquatic Sciences, 25(4), 311-314. [in Turkish] http://doi.org/10.12714/ egejfas.2008.25.4.5000156614

Özbek, M. (2011). An overview of the Gammarus Fabricus (Gammaridae: Amphipoda) species of Turkey, with an updated checklist. Zoology in the Middle East, 53, 71-78. [CrossRef]

Özbek, M. (2016). Epigean amphipod fauna of Gönen stream (western Anatolia, Turkey), with the description of Gammarus gonensis sp. nov. Turkish Journal of Zoology, 40, 336-344. [CrossRef]

Özbek, M., Balık, S. \& Topkara, E. T. (2009). Contribution to the knowledge on the distribution of Malacostraca (Crustacea) species of central and southern Anatolia, with some ecological notes. Turkish Journal of Zoology, 33, 47-55.

Özbek, M., Balık, S. \& Ustaoğlu, M. R. (2004). Malacostraca (Crustacea) fauna of Yuvarlak Stream (Köyceğiz- Muğla). Turkish Journal of Zoology, 28, 321-327.
Özbek, M., Bakır, K. \& Ustaoğlu, M. R. (2016). Malacostraca fauna of the Karina Lagoon (Aydın). Ege Journal of Fisheries and Aquatic Sciences, 33(1), 13-19 [in Turkish]. [CrossRef]

Özbek, M. \& Özkan, N. (2017). Amphipoda (Crustacea: Malacostraca) fauna of the inland-waters of Gökçeada Island. Ege Journal of Fisheries and Aquatic Sciences, 34(1), 63-67 [in Turkish]. [CrossRef]

Özbek, M., Özkan, N. \& Çamur-Elipek, B. (2017). Freshwater and brackish amphipods (Crustacea: Amphipoda) from Turkish Thrace region (including Çanakkale province). Acta Zoologica Bulgarica, 69(4), 493-499.

Özbek, M., Öztürk, H. H. \& Özkan, N. (2015). Gammaridae (Amphipoda) fauna of the inland-waters of Marmara and Paşalimanı islands and Kapıdağ peninsula. Ege Journal of Fisheries and Aquatic Sciences, 32(4), 213-216 [in Turkish]. [CrossRef]

Özbek, M. \& Sket, B. (2019). A new Rhipidogammarus (Crustacea: Amphipoda) species from Turkey: first record of the genus from the Eastern Mediterranean Region, with an identification key for the genus. Glasnik Odjeljenja prirodnih nauka, 23, 83-98.

Özbek, M., Topkara, E. T. (2007). Supplementary data on morphology, distribution, and ecology of Gammarus dorsosetosus Mateus and Mateus, 1990 (Amphipoda, Gammaridae). Crustaceana, 80, 641-653. [CrossRef]

Özbek, M. \& Ustaoğlu, M. R. (1998). The Amphipoda (CrustaceaArthropoda) fauna of Izmir and adjacent areas inland-waters. Ege Journal of Fisheries and Aquatic Sciences, 15(3-4), 211-231. [in Turkish]

Özbek, M. \& Ustaoğlu, M. R. (2005). Taxonomical investigation of Lake District inland waters Malacostraca (Crustacea-Arthropoda) fauna. Ege Journal of Fisheries and Aquatic Sciences, 22(3-4), 357-362. [in Turkish].

Özkan, N. (2009). Chironomidae (Diptera) and Gammaridae (Amphipoda) fauna in Dupnisa Cave (Sarpdere Village, Demirköy, Kırklareli). Ege Journal of Fisheries and Aquatic Sciences, 26(1), 7-10.

Pinkster, S. (1993). A revision of the genus Echinogammarus Stebbing, 1899, with some notes on related genera (Crustacea, Amphipoda). Memorie Del Museo Civico Di Storia Naturale, (ser 2) 10, 1-185.

Ruffo, S. (1951). Sulla presenza di Gammarus (Rivulogammarus) lacustris G. O. Sars nell'Appennino ligure e nuovi reperti della specie per laghi alpine. Doriana ,1(19), 1-8.

Sarı, H. M., Balık, S., Özbek, M. \& Aygen, C. (2001). The macro and meiobenthic invertebrate fauna of Lake Bafa. Anadolu University Journal of Science and Technology, 2(2), 285-291. [in Turkish]

Sars, G. O. (1863). Beretning om en i Sommeren 1862 foretagen zoologisk Reise i Christianias og Trondhjems Stifter. Nyt Magazin for Naturvidenskaberne, 12, 193-252.

Schäferna, K. (1923). Amphipoda balcanica, spolu s poznámkami o jiných sladkovodních Amphipodech. Mémoires de la Société Royale des Sciences de Bohème Prague Annee 1921-1922, 12, 1-111.

Schellenberg, A. (1937). Kritische Bemerkungen zur Systematik der Susswassergammariden. Zoologische Jahrbucher. Abteilung fur Systematik, Okologie und Geographie der Tiere, 69, 469-516.

Stock, J. H. (1967) A revision of the European species of the Gammarus locusta group (Crustacea, Amphipoda). Zoologische Verhandelingen, 90, 1-56.

Şirin, Ü., Çalışkan, H. \& Ijpek, M. (2009). On the occurrence of Gammarus uludagi G. Karaman, 1975 (Amphipoda, Gammaridae) in Kazdaglari. Sakarya University The Journal of Arts and Science, 11(2), 29-34.

Tareen, I. U. (1974). Limnological investigations of Gölcük Lake (ÖdemişTurkey). PhD Thesis, Ege University, Turkey, 122 p. [in Turkish]

Ustaoğlu, M. R., Balık, S. \& Özbek, M. (1998). Malacostraca (ArthropodaCrustacea) fauna of Bafa Lake. Ege Journal of Fisheries and Aquatic Sciences 15(3-4). 263-267. [in Turkish]

Ustaoğlu, M. R., Balık, S. \& Özbek, M. (2000). Malacostraca (ArthropodaCrustacea) fauna of Akgöl and Lake Gebekirse (Selçuk-İzmir). In: XV. National Biology Congress (pp. 217-222). Ankara University, Turkey. [in Turkish] 
Ustaoğlu, M. R., Balık, S. \& Özbek, M. (2004). Contributions to the knowledge of Malacostraca (Crustacea) fauna of the Taurus Mountains district (Southern Anatolia). Turkish Journal of Zoology, 28, 91-94.

Ustaoğlu, M. R., Balık, S., Sarı, H. M., Özdemir Mis, D., Aygen, C., Özbek, M., İlhan, A., Taşdemir, A., Yıldız, S. \& Topkara, E. T. (2008). A faunal study of the glacier lakes and rivers on Uludağ (Bursa)
Mountain. Ege Journal of Fisheries and Aquatic Sciences, 25(4), 295-299. [in Turkish]

Vávra, V. (1905). Rotatorien und Crustaceen. Wien: Annalen des K. K. Naturhistorischen Hofmuseums, 20, 106-113.

Yeşilmen, T. Ö., Kırgız, T. (1996). Freshwater Gammarus (Gammaridae) species of Kirklareli province. Turkish Journal of Zoology, 20(Supplement), 315-318. 